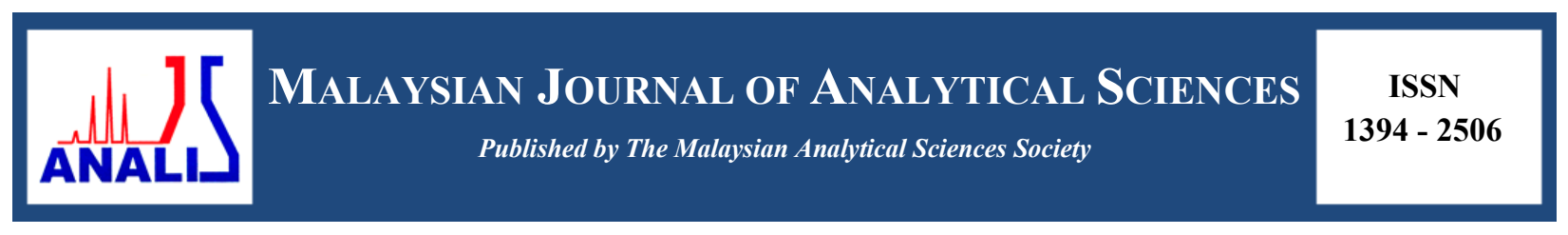

\title{
THE ANALYSIS OF THERMAL DECOMPOSITION PRODUCTS GENERATED FROM PORCINE TISSUES EXPOSED TO OUTDOOR BURNING CONDITIONS
}

\author{
(Analisis Produk Penguraian Haba Yang Terhasil Daripada Tisu Khinzir Yang Terdedah Kepada \\ Pembakaran Terbuka)
}

\author{
Gina Francesca Gabriel, Azima Ismail, Atiah Ayuni, Khairul Osman, Noor Hazfalinda Hamzah* \\ Forensic Science Program, Faculty of Health Sciences, \\ Universiti Kebangsaan Malaysia, 43600 UKM Bangi, Selangor, Malaysia \\ *Corresponding author: raviera@yahoo.com
}

Received: 28 August 2016; Accepted: 16 March 2017

\begin{abstract}
Volatile products commonly known as pyrolytic products, are thermal decomposition products generated from the various fuels that are present at a fire scene due to heat exposure. When a fire scene involves human remains, the volatile species generated from the remains can be mistaken with others residues due to the presence of interfering products or ignitable liquid residues from the fire scene. Knowledge of the type of products generated from human remains in real life fire scenarios is crucial under these circumstances. Thus, this study was executed to test the robustness and validity of the pyrolytic data generated from porcine tissue under indoor laboratory burning conditions to those generated under outdoor burning conditions. Porcine bone samples were burnt under outdoor conditions until the ignition of fat occurred (temperatures exceeding $250{ }^{\circ} \mathrm{C}$ ). The pyrolytic products generated were absorbed onto activated carbon tablets that were incubated in an oven for 16 hours at $80{ }^{\circ} \mathrm{C}$ and then desorbed with pentane and injected into the Gas Chromatography-Mass Spectrometry (GC-MS). The 60 pyrolytic profiles obtained were in the range of $n$-alkanes, $n$-alkenes, $n$-aldehydes, aromatics and nitriles, similar to those obtained from the indoor laboratory burning data but with the additional presence of $n$-aldehydes. Results from this study has indicated that the human pyrolytic data model generated indoors is a good representative of outdoor burning conditions and has also successfully clarified the inconsistencies in terms of the presence and absence of $n$-aldehydes from porcine and human pyrolytic data.
\end{abstract}

Keywords: thermal decomposition, porcine bone, pyrolytic products, activated carbon tablet, gas chromatography-mass spectrometry

\begin{abstract}
Abstrak
Sebatian meruap mudah kebiasaannya dikenali sebagai produk pirolitik merupakan produk penguraian menggunakan haba yang terhasil daripada pelbagai jenis bahan api yang terdapat di sekitar kawasan kebakaran disebabkan oleh pendedahan kepada haba. Apabila terdapat sisa kebakaran yang melibatkan tulang manusia, spesis sebatian mudah meruap yang dikesan boleh disalah anggap dengan sisa lain disebabkan produk luar atau pun sisa cecair mudah terbakar. Oleh yang demikian, kajian ini bertujuan untuk mengenalpasti ketepatan dan kesahihan data pirolitik yang terhasil daripada tisu khinzir melalui pembakaran secara tertutup di dalam makmal dengan pembakaran secara terbuka. Tulang khinzir dibakar secara terbuka sehingga suhu nyalaan pembakaran lemak tulang berlaku (suhu melebihi $250^{\circ} \mathrm{C}$ ). Produk pirolisis yang dijana diserap menggunakan penjerapan karbon teraktif dalam bentuk tablet dengan menggunakan inkubator selama 16 jam pada suhu $80{ }^{\circ} \mathrm{C}$ dan seterusnya dinyaherap dengan pentana dan dianalisis menggunakan Kromatografi Gas-Spektrometri Jisim (GC-MS). Sejumlah 60 jenis produk pirolitik yang terhasil adalah sebatian kompaun $n$-alkana, $n$-alkena, $n$-aldehid, aromatik dan sebatian nitril. Produk yang terhasil adalah sama dengan data pembakaran di dalam makmal tetapi dengan penambahan kehadiran $n$-aldehid. Keputusan kajian ini menunjukkan bahawa model data pirolitik manusia yang terhasil daripada pembakaran dalam makmal boleh menjadi rujukan yang baik untuk
\end{abstract}


situasi kebakaran terbuka, dan berjaya menjelaskan percanggahan dari segi kehadiran dan ketiadaan $n$-aldehid daripada data pirolitik khinzir dan manusia.

Kata kunci: penguraian menggunakan haba, tulang khinzir, produk pirolitik, penjerapan karbon teraktif, kromatografi gasspektrometri jisim

\section{Introduction}

Fire is often used as a tool to conceal and destroy evidence of a crime, particularly in terms of obscuring the detection of human remains $[1,2]$ as it is commonly believed that fire or the effects of fire can completely destroy any forensic evidence present. When a human body is exposed to fire, a variety of physical, chemical and biological changes are exerted to the muscles, tissues and bony structure of the body [3 - 5]. These changes can indefinitely pose difficulty to a fire investigator, in locating and identifying human remains, if any, at a fire scene. Moreover, it is a daunting task to differentiate between small fragments of bone or teeth that are severely burnt and/or dismembered from charred fragments of fire debris [3, 4], even for trained anthropologies [3]. This is due to the similarity in overall appearance for both components, especially when mixed together with various fuel loads at the fire scene. The lack of knowledge and experience in locating these burnt remains, in addition to the limited research data available in identifying the pyrolytic profile of burnt human remains [6] as opposed to the vastly known and readily available pyrolytic database of ignitable liquid residue (ILR) could potentially lead investigators to a false positive or false negative conclusion [7].

Previous work in the field of pyrolytic data from human and porcine tissue were conducted by DeHaan et al. [8], in which they determined the presence of $n$-alkanes, $n$-aldehydes, $n$-alkenes and aromatic compounds from these samples burnt in a contained microfurnace at $300{ }^{\circ} \mathrm{C}, 500{ }^{\circ} \mathrm{C}$ and $700{ }^{\circ} \mathrm{C}$, respectively. In the recent work conducted by Agu [9] and Gabriel [7] on human and porcine tissue exposed to an open flame but under controlled laboratory conditions, identified the consistent presence of volatile compounds in the range of $n$-alkanes, $n$-alkenes, aromatic alkenes, $n$-alkyl-benzenes and nitriles when exposed to temperatures between $500{ }^{\circ} \mathrm{C}$ to $800{ }^{\circ} \mathrm{C}$. No $n$-aldehydes were present at these temperature ranges as opposed to DeHaan et al.'s [8] work. However, both Gabriel [7] and Agu [9] identified the presence of $n$-aldehydes at pre-ignition temperatures (below $300{ }^{\circ} \mathrm{C}$ ). Variations in temperature, methodologies and particularly exposure conditions (indoor and outdoor, contained and open) could certainly cause these documented discrepancies in the pyrolytic profile obtained from human and porcine tissue.

This paper addresses these issues, by testing the robustness of the pyrolytic data and key indicators established from porcine tissue under controlled laboratory conditions to those generated from outdoor conditions. The similarity and differences in terms of the chemical fingerprint of thermal decomposition products from porcine tissue; as a representation of human tissue [7,8], exposed under both; indoor laboratory and outdoor conditions were analysed, compared and reported.

\section{Materials and Methods}

This study is an extension of the work executed by Gabriel [7], who conducted indoor laboratory burning using porcine bone. This study adapted similar experimental procedures but varied the conditions to outdoor burning.

\section{Standard test mixture}

A $1 \mathrm{mg} / \mathrm{mL}$ standard solution (Sigma Aldrich, UK) containing 12 high purity compounds; benzene, toluene, octane, ethyl-benzene, $p$-xylene, propyl-benzene, decane, butyl-benzene, dodecane, tridecane, tetradecane and pentadecane, were prepared and placed into six individual gas chromatography (GC) vials (Agilent, UK). The six vials were then placed into an auto-sampler of a Gas Chromatography-Mass Spectrometry (GC-MS) (Shimadzu, UK) and injected into the instrument. Information from the individual peak area and retention time of each compound provided data that was then used to test the robustness of the instrument and analysis by revealing the relative standard deviation (RSD) values.

\section{GC-MS condition}

The temperature of the injector was maintained at $250{ }^{\circ} \mathrm{C}$, set to splitless mode with a $20: 1$ split ratio and 32.7 $\mathrm{mL} / \mathrm{min}$ split flow. A $128-0122 \mathrm{DB}-1 \mathrm{MS}$ column $(22 \mathrm{~mm}$ length $\times 0.2 \mathrm{~mm}$ inner diameter $\times 0.33 \mu \mathrm{m}$ film 
thickness) (Crawford Scientific, UK) was used in this experiment. Helium was used as a carrier gas, flowing at a constant rate of $1 \mathrm{~mL} / \mathrm{min}$. The oven temperature was set at $40{ }^{\circ} \mathrm{C}$ and held for five minutes, then ramped at 15 ${ }^{\circ} \mathrm{C} /$ min to reach the final temperature of $280{ }^{\circ} \mathrm{C}$ and held for two minutes. The temperature of the detector was maintained at $250^{\circ} \mathrm{C}$. Data collected from the GC-MS analysis were identified based on their $\mathrm{m} / \mathrm{z}$ values that were matched against the standard test mixture and National Institute of Standards and Technology (NIST) (NIST/EPA/NIH Mass Spectral Library).

\section{Sample preparation}

Porcine femur bones in the range between five to six months of age were utilised in this work, purchased from the Kajang Wet Market, Selangor. The bones were labelled according to the date purchased and stored in a laboratory freezer at $-21^{\circ} \mathrm{C}$. Before cutting, the bones were defrosted at room temperature for 30 to 40 minutes. The epiphysis of each bone was detached using a bench vice and a hacksaw in order to reduce variations in the composition of the bone samples that could potentially alter the resultant pyrolytic data [7]. Scissors and tweezers were used to remove any residual soft tissues on the bone. The remaining diaphysis was then cut into $25 \pm 1.5 \mathrm{~g}$ sizes as recommended in the indoor laboratory burning experiment, to be the optimum size for best pyrolytic data. Each $25 \pm 1.5 \mathrm{~g}$ bone fragment was then placed into individual $125 \mathrm{~mL}$ aluminium tin can (WA Products, UK) respectively. The process above was repeated until six $25 \pm 1.5 \mathrm{~g}$ bone samples were obtained.

\section{Thermal decomposition process}

The outdoor burning experiment was set up at the Forensic Science Simulation Site, UKM, Bangi, Selangor. A retort stand was placed on a flat ground and the tin can (with the lid removed) containing the bone sample was clamped onto it to hold it in place during the burning process. The sample was heated using a portable gas canister burner (Sigma Aldrich, UK) placed under the tin can at approximately $3 \mathrm{~cm}$ from the tip of the canister to the base of the tin. A k-thermocouple connected to a digital thermometer model 6802 II (Signstek Ltd, London) was used to monitor the temperature of the bone sample during pyrolysis. The sample was allowed to burn until the ignition of fat occurred and was allowed to burn for five minutes thereafter. Ten seconds before the five minute mark, the gas canister and k-thermocouple were removed swiftly and an empty lid was placed over the tin can in order to extinguish the flame. The covered tin can containing the burnt sample was then left to cool at room temperature for four minutes as recommended in the indoor laboratory burning experiment.

The empty lid was then replaced with another lid containing an activated carbon tablet, which was hooked onto a paper clip and held on the lid with the use of magnets. The tin was sealed shut and incubated in oven for 16 hours at $80{ }^{\circ} \mathrm{C}[10]$. After the incubation process, the activated carbon tablet was removed and placed into a $1 \mathrm{~mL} \mathrm{GC}$ vial (Agilent, UK) and desorbed with $1 \mathrm{~mL}$ of pentane. The GC vial containing the desorbed activated carbon in pentane was then introduced into the GC-MS. The entire process was repeated until six sets of results were obtained. The similarities and differences in terms of volatile compound detected in outdoor burning conditions were then compared to the results obtained from the indoor laboratory burning conditions.

\section{Results and Discussion}

Porcine tissue was chosen as a representative of human tissue as Gabriel [7], Agu [9] and DeHaan et al. [8] identified clear similarities with minor differences in the pyrolysis products generated across both tissues. Porcine bone, in particular, possesses the closest resemblance to human bone as compared to other animals [11] in terms of its morphology, bone remodelling process and structure $[12,13]$, diameter and the area of femoral cross-sectional, structure of lamella bones and regeneration rate [11].

Across the six replicates, volatile compounds in the range of $\mathrm{C}_{7}$ to $\mathrm{C}_{17} n$-alkanes and $\mathrm{C}_{4}$ to $\mathrm{C}_{17} n$-alkenes as well as $n$ cycloalkanes, aromatics, $n$-alkyl-benzenes, $\mathrm{C}_{5}-\mathrm{C}_{6} n$-aldehydes, nitriles, furans, disulfide alcohol and dienes were detected, as displayed in Table 1 . Table 1 also shows the volatile compounds that are consistently present across all six replicates of burnt porcine bone samples, namely; $\mathrm{C}_{8}$ to $\mathrm{C}_{15} n$-alkanes and $\mathrm{C}_{4}$ to $\mathrm{C}_{16} n$-alkenes together with $n$ cycloalkanes, aromatics, $n$-alkyl-benzenes, $\mathrm{C}_{5} n$-aldehyde and a nitrile. Six individual Total Ion Chromatograms (TIC) for each set are illustrated in Figure 1 till Figure 6, respectively. 
Table 1. Volatile compounds generated from six outdoor burning of porcine bone samples. A tick represents that the compound is present in the sample

\begin{tabular}{|c|c|c|c|c|c|c|c|c|}
\hline \multirow[t]{2}{*}{ No } & \multirow{2}{*}{$\begin{array}{l}\text { Retention } \\
\text { Time (min) }\end{array}$} & \multirow[t]{2}{*}{ Compound } & \multicolumn{6}{|c|}{ Set } \\
\hline & & & 1 & 2 & 3 & 4 & 5 & 6 \\
\hline 1. & 1.12 & 1-butene & $\checkmark$ & $\checkmark$ & $\checkmark$ & $\checkmark$ & $\checkmark$ & $\checkmark$ \\
\hline 2. & 1.81 & methyl-cyclopentane & $\checkmark$ & $\checkmark$ & $\checkmark$ & $\boldsymbol{\nu}$ & $\checkmark$ & $\boldsymbol{\nu}$ \\
\hline 3. & 1.88 & butanenitrile & & $\checkmark$ & $\checkmark$ & $\checkmark$ & $\checkmark$ & $\checkmark$ \\
\hline 4. & 1.99 & benzene & $\checkmark$ & $\checkmark$ & $\checkmark$ & $\checkmark$ & $\boldsymbol{\nu}$ & 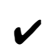 \\
\hline 5. & 2.08 & cyclohexane & & $\checkmark$ & $\checkmark$ & $\checkmark$ & & $\nu$ \\
\hline 6. & 2.23 & pentanal & $\checkmark$ & $\checkmark$ & $\checkmark$ & $\checkmark$ & $\checkmark$ & $\checkmark$ \\
\hline 7. & 2.41 & 1-heptene & $\checkmark$ & $\checkmark$ & $\checkmark$ & $\checkmark$ & $\checkmark$ & $\checkmark$ \\
\hline 8. & 2.49 & 3-methyl-butanitrile & $\checkmark$ & $\checkmark$ & $\checkmark$ & $\checkmark$ & $\boldsymbol{\nu}$ & $\boldsymbol{\nu}$ \\
\hline 9. & 2.56 & heptane & $\checkmark$ & $\checkmark$ & $\checkmark$ & $\checkmark$ & $\checkmark$ & $\checkmark$ \\
\hline 10. & 2.63 & 2-heptene & $\checkmark$ & $\checkmark$ & $\checkmark$ & $\checkmark$ & $\checkmark$ & $\checkmark$ \\
\hline 11. & 2.70 & 2-ethyl-furan & & $\boldsymbol{\nu}$ & $\checkmark$ & $\checkmark$ & & $\boldsymbol{v}$ \\
\hline 12. & 2.75 & 3-heptene & & $\checkmark$ & $\checkmark$ & $\checkmark$ & $\checkmark$ & $\checkmark$ \\
\hline 13. & 2.85 & methyl-cyclohexane & & $\checkmark$ & $\checkmark$ & $\checkmark$ & & $\nu$ \\
\hline 14. & 2.93 & dimethyl-disulfide & $\checkmark$ & & $\checkmark$ & $\checkmark$ & $\checkmark$ & $\checkmark$ \\
\hline 15. & 3.05 & ethyl-cyclopentane & & $\checkmark$ & $\checkmark$ & $\checkmark$ & & $\checkmark$ \\
\hline 16. & 3.49 & toluene & $\checkmark$ & $\checkmark$ & $\checkmark$ & $\checkmark$ & $\checkmark$ & $\checkmark$ \\
\hline 17. & 3.75 & cycloheptene & & $\boldsymbol{\nu}$ & $\checkmark$ & $\boldsymbol{\nu}$ & $\boldsymbol{\nu}$ & $\nu$ \\
\hline 18. & 4.13 & hexanal & $\checkmark$ & & $\checkmark$ & $\checkmark$ & & $\nu$ \\
\hline 19. & 4.47 & 1 -octene & $\checkmark$ & $\checkmark$ & $\checkmark$ & $\checkmark$ & $\checkmark$ & $\boldsymbol{\nu}$ \\
\hline 20. & 4.78 & 3-methyl-1-heptene & & $\boldsymbol{\nu}$ & $\checkmark$ & $\boldsymbol{\nu}$ & & $\boldsymbol{v}$ \\
\hline 21. & 4.86 & octane & $\checkmark$ & $\checkmark$ & $\checkmark$ & $\checkmark$ & $\checkmark$ & $\nu$ \\
\hline 22. & 5.00 & 2-octene & $\checkmark$ & $\boldsymbol{\nu}$ & $\checkmark$ & $\boldsymbol{v}$ & $\boldsymbol{\nu}$ & $\checkmark$ \\
\hline 23. & 5.27 & 4-octene & & $\checkmark$ & $\checkmark$ & $\checkmark$ & $\checkmark$ & $\checkmark$ \\
\hline 24. & 5.72 & propyl-cyclohexane & & $\checkmark$ & $\checkmark$ & $\checkmark$ & & $\nu$ \\
\hline 25. & 6.10 & 1,8 -nonadiene & & $\checkmark$ & $\checkmark$ & $\checkmark$ & & $\nu$ \\
\hline 26. & 6.19 & ethyl-benzene & $\checkmark$ & $\boldsymbol{v}$ & $\checkmark$ & 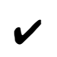 & $\checkmark$ & $\nu$ \\
\hline 27. & 6.42 & $o$-xylene & & $\checkmark$ & $\checkmark$ & $\checkmark$ & & $\boldsymbol{V}$ \\
\hline 28. & 6.60 & 2-butyl-furan & & $\checkmark$ & $\checkmark$ & $\checkmark$ & & $\checkmark$ \\
\hline 29. & 6.82 & benzo-cycobutene & & $\checkmark$ & $\boldsymbol{\nu}$ & $\checkmark$ & & $\checkmark$ \\
\hline 30. & 6.92 & $p$-xylene & & $\checkmark$ & $\checkmark$ & $\checkmark$ & & $\checkmark$ \\
\hline 31. & 7.23 & 1-nonene & $\checkmark$ & $\checkmark$ & $\checkmark$ & $\checkmark$ & $\checkmark$ & $\boldsymbol{v}$ \\
\hline 32. & 7.47 & nonane & $\checkmark$ & $\checkmark$ & $\checkmark$ & $\checkmark$ & $\checkmark$ & $\checkmark$ \\
\hline 33. & 7.53 & 3-nonene & & $\checkmark$ & $\checkmark$ & $\checkmark$ & $\boldsymbol{v}$ & $\boldsymbol{v}$ \\
\hline 34. & 7.68 & 4-nonene & & $\boldsymbol{v}$ & $\checkmark$ & $\boldsymbol{\nu}$ & & $\boldsymbol{v}$ \\
\hline 35. & 7.92 & 3-cyclohexyl-1-cyclohexene & & $\checkmark$ & $\boldsymbol{\nu}$ & $\checkmark$ & $\boldsymbol{\nu}$ & $\boldsymbol{v}$ \\
\hline 36. & 8.01 & ethyl-cylopentane & & $\checkmark$ & $\checkmark$ & $\checkmark$ & & $\boldsymbol{\nu}$ \\
\hline 37. & 8.15 & propyl-benzene & $\checkmark$ & $\checkmark$ & $\checkmark$ & $\checkmark$ & $\boldsymbol{v}$ & $\boldsymbol{\nu}$ \\
\hline 38. & 8.23 & 3,4-nonadiene & & $\boldsymbol{\nu}$ & $\checkmark$ & $\boldsymbol{v}$ & $\boldsymbol{\nu}$ & $\boldsymbol{v}$ \\
\hline 39. & 8.57 & 1-ethyl-4-methyl-benzene & & $\checkmark$ & $\boldsymbol{\nu}$ & $\checkmark$ & & $\boldsymbol{V}$ \\
\hline 40. & 8.83 & 2-pentyl-furan & $\checkmark$ & & $\checkmark$ & $\checkmark$ & $\checkmark$ & $\checkmark$ \\
\hline 41. & 8.98 & 1-decene & $\checkmark$ & $\checkmark$ & $\checkmark$ & $\checkmark$ & $\checkmark$ & $\checkmark$ \\
\hline 42. & 9.03 & nonanol & & & $\checkmark$ & $\boldsymbol{\nu}$ & & $\boldsymbol{V}$ \\
\hline
\end{tabular}


Table 1 (cont'd). Volatile compounds generated from six outdoor burning of porcine bone samples. A tick represents that the compound is present in the sample

\begin{tabular}{|c|c|c|c|c|c|c|c|c|}
\hline \multirow[t]{2}{*}{ No } & \multirow{2}{*}{$\begin{array}{l}\text { Retention } \\
\text { Time (min) }\end{array}$} & \multirow[t]{2}{*}{ Compound } & \multicolumn{6}{|c|}{ Set } \\
\hline & & & 1 & 2 & 3 & 4 & 5 & 6 \\
\hline 43. & 9.16 & decane & $\checkmark$ & $\checkmark$ & $\checkmark$ & $\checkmark$ & $v$ & $\checkmark$ \\
\hline 44. & 9.72 & butyl-benzene & $\checkmark$ & $\checkmark$ & $\checkmark$ & $\nu$ & $\checkmark$ & $\checkmark$ \\
\hline 45. & 10.33 & 1-undecene & $\boldsymbol{\nu}$ & $\nu$ & $\checkmark$ & $\checkmark$ & $\checkmark$ & $\checkmark$ \\
\hline 46. & 10.47 & undecane & $\boldsymbol{\nu}$ & $\nu$ & $\checkmark$ & $\checkmark$ & $\checkmark$ & $\checkmark$ \\
\hline 47. & 10.96 & pentyl-benzene & $\checkmark$ & $\checkmark$ & $\checkmark$ & $\checkmark$ & $v$ & $\checkmark$ \\
\hline 48. & 11.45 & 1-dodecene & $\checkmark$ & $\checkmark$ & $\checkmark$ & $\checkmark$ & $\checkmark$ & $\checkmark$ \\
\hline 49. & 11.58 & dodecane & 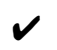 & $\nu$ & $\nu$ & $\nu$ & 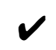 & $\checkmark$ \\
\hline 50. & 12.47 & 1-tridecene & $\checkmark$ & $\checkmark$ & $\checkmark$ & $\checkmark$ & $\nu$ & $\checkmark$ \\
\hline 51. & 12.58 & tridecane & $\checkmark$ & $\nu$ & $\checkmark$ & $\nu$ & $\nu$ & $\checkmark$ \\
\hline 52. & 13.39 & 1-tetradecene & $\checkmark$ & $\nu$ & $\nu$ & $\nu$ & $\checkmark$ & $\checkmark$ \\
\hline 53. & 13.49 & tetradecane & $\checkmark$ & $\nu$ & $\nu$ & $\checkmark$ & $\checkmark$ & $\checkmark$ \\
\hline 54. & 14.26 & 1-pentadecene & $\checkmark$ & & $\checkmark$ & & & $\checkmark$ \\
\hline 55. & 14.35 & pentadecane & $\checkmark$ & $\checkmark$ & $\checkmark$ & $\checkmark$ & $\boldsymbol{v}$ & $\checkmark$ \\
\hline 56. & 14.78 & 1-hexadecene & $\checkmark$ & $\checkmark$ & $\nu$ & $\checkmark$ & $\checkmark$ & $\checkmark$ \\
\hline 57. & 15.15 & hexadecane & $\checkmark$ & $\nu$ & $\checkmark$ & $\boldsymbol{\nu}$ & & $\checkmark$ \\
\hline 58. & 15.73 & 1-heptadecene & $\checkmark$ & & $\checkmark$ & $\checkmark$ & & $\checkmark$ \\
\hline 59. & 15.92 & heptadecane & $\checkmark$ & $\checkmark$ & $\checkmark$ & $\checkmark$ & & $\checkmark$ \\
\hline 60. & 17.13 & hexadecanitrile & & $\checkmark$ & $\nu$ & $\checkmark$ & & \\
\hline
\end{tabular}

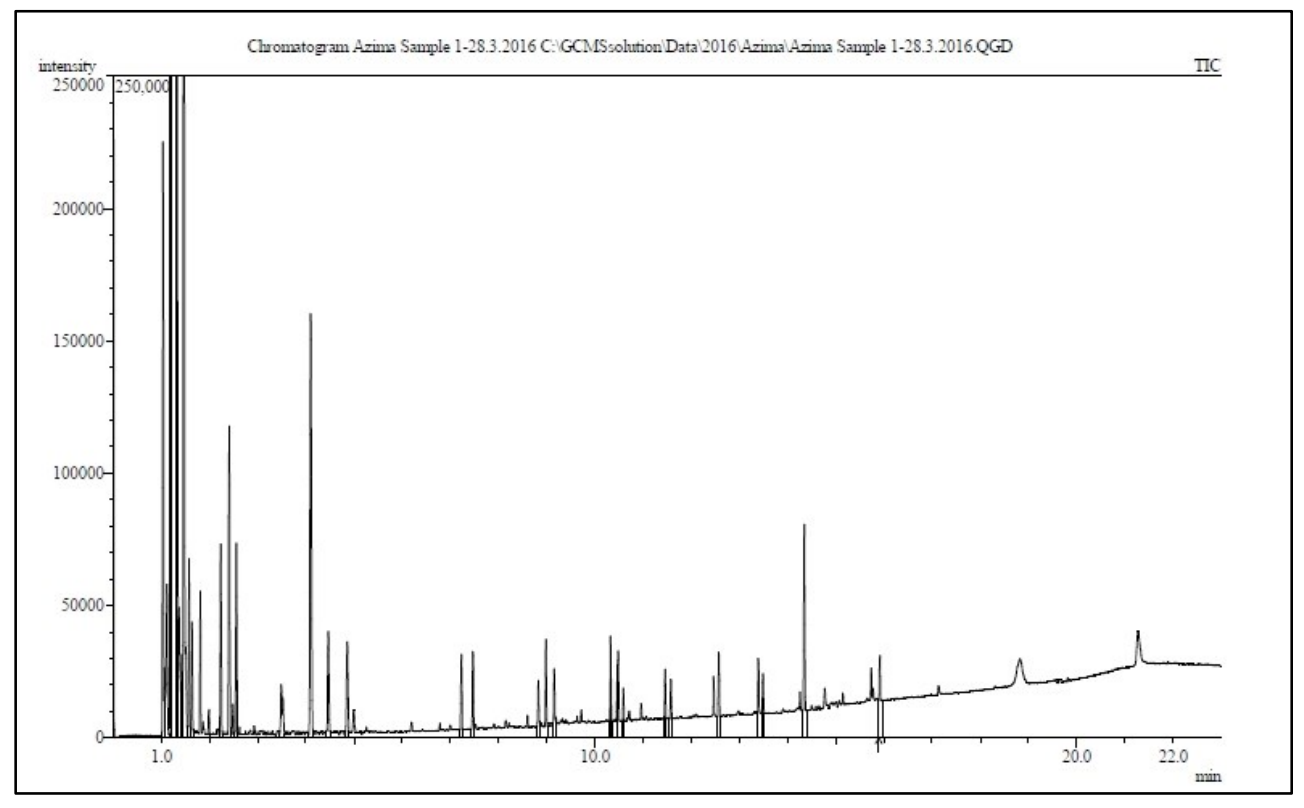

Figure 1. TIC of burned porcine bone (Set 1) 
Gabriel et al: THE ANALYSIS OF THERMAL DECOMPOSITION PRODUCTS GENERATED FROM PORCINE TISSUES EXPOSED TO OUTDOOR BURNING CONDITIONS

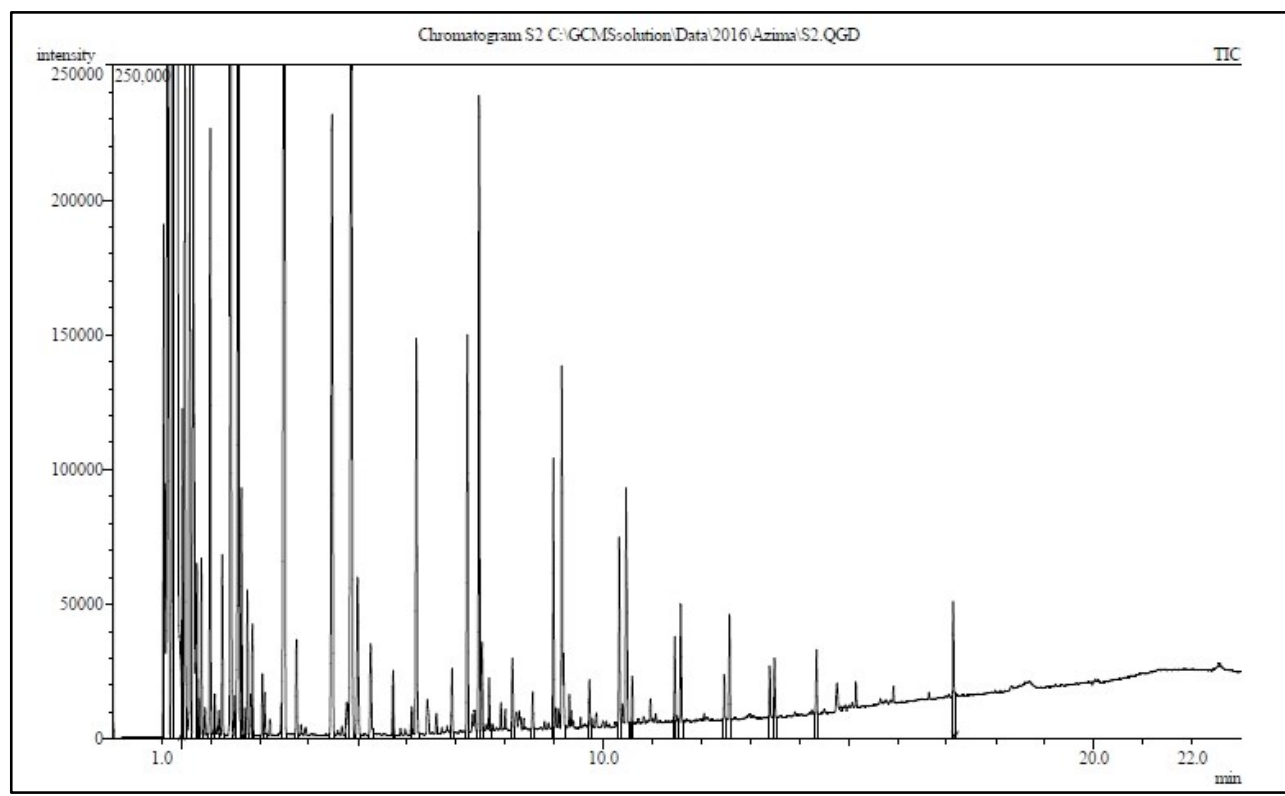

Figure 2. TIC of burned porcine bone (Set 2)

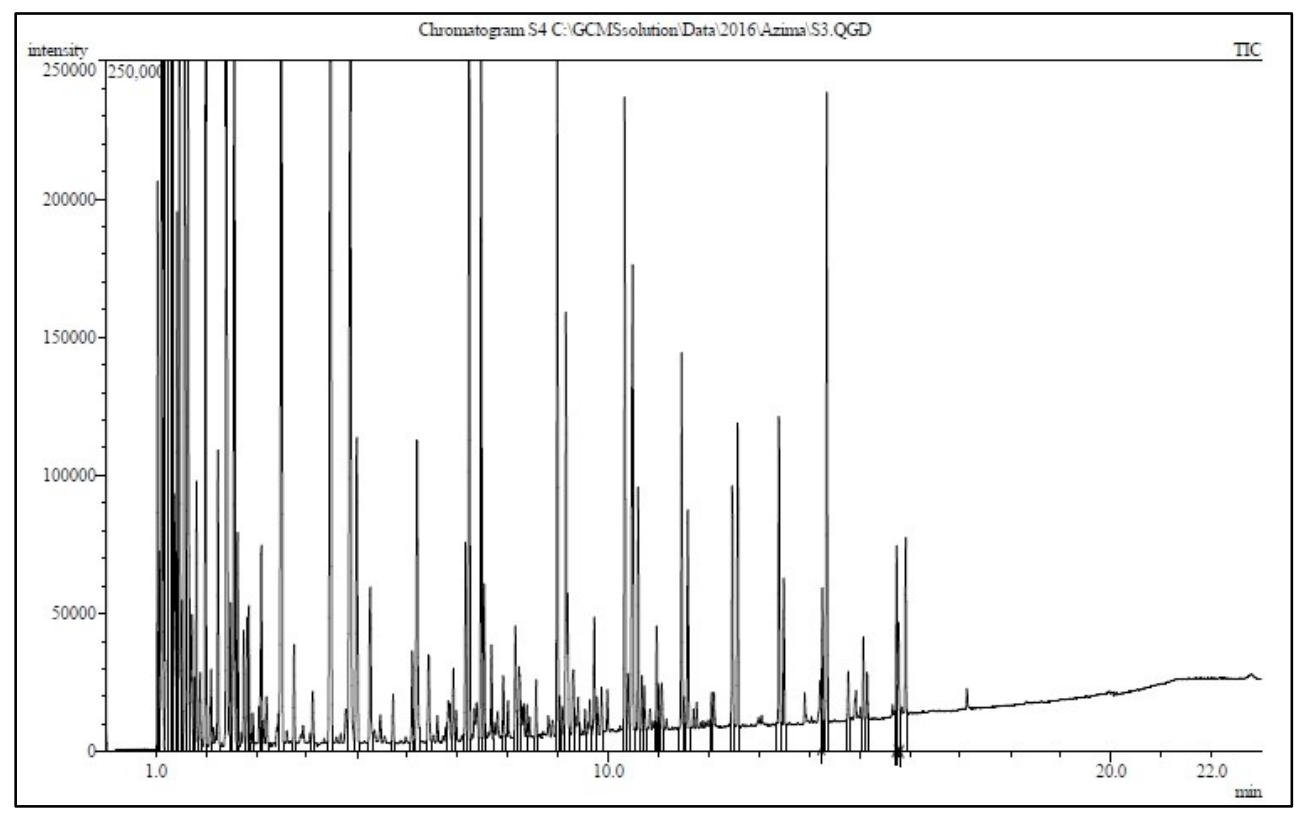

Figure 3. TIC of burned porcine bone (Set 3) 


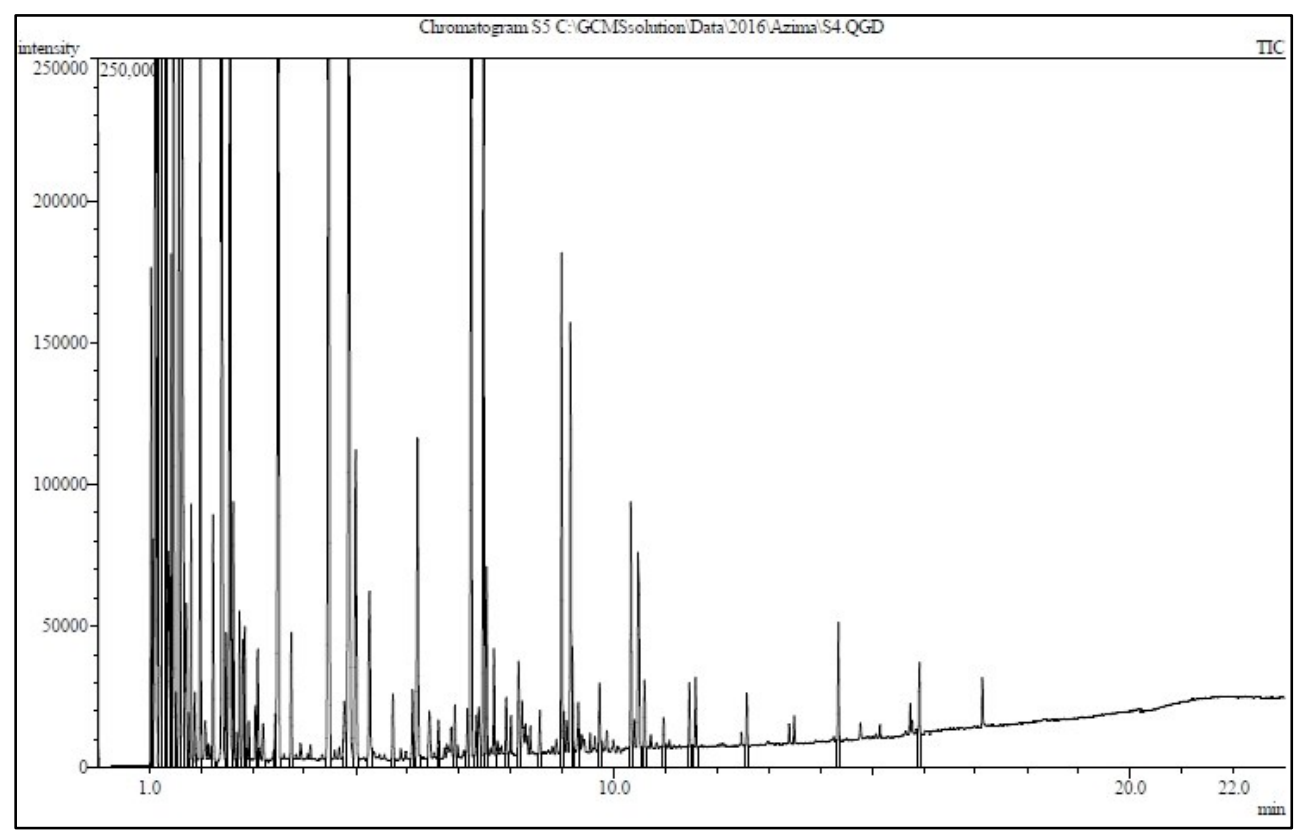

Figure 4. TIC of burned porcine bone (Set 4)

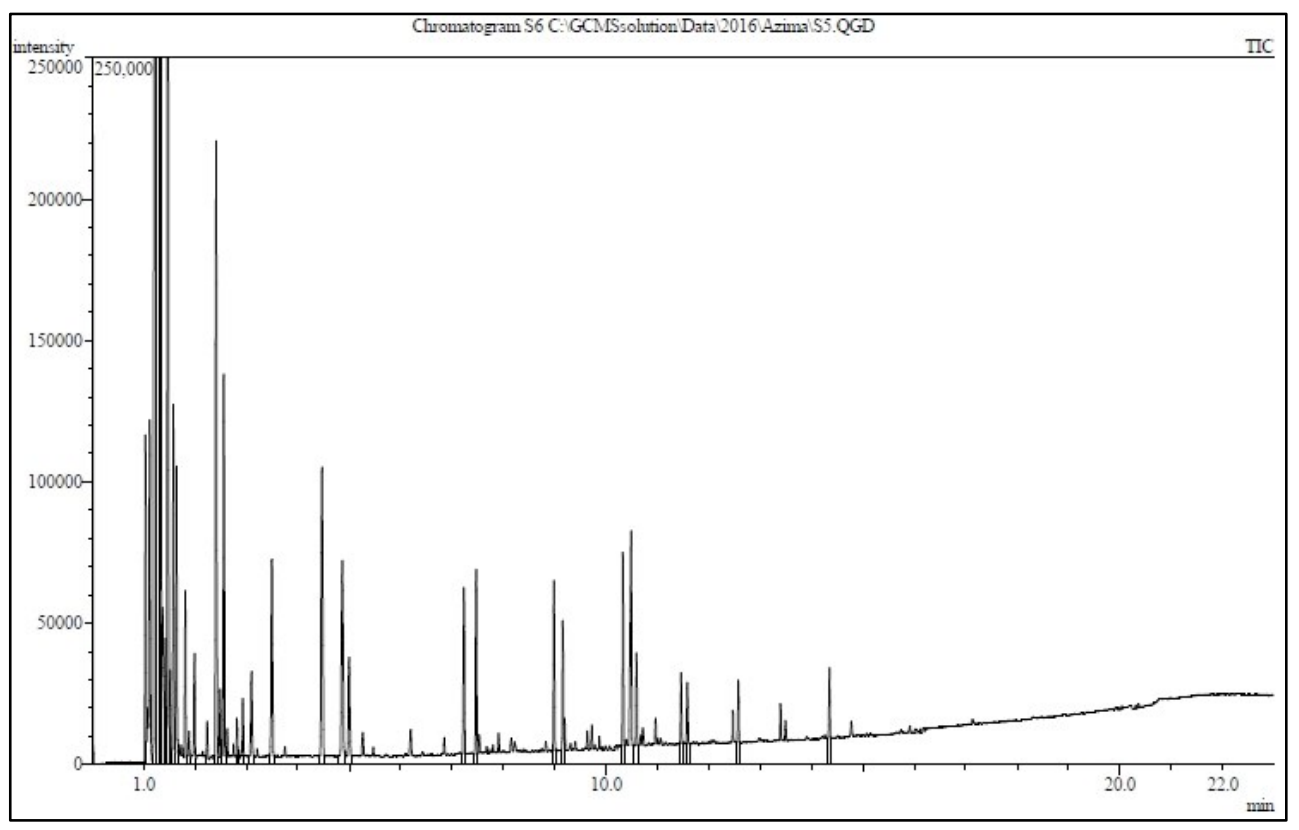

Figure 5. TIC of burned porcine bone (Set 5) 


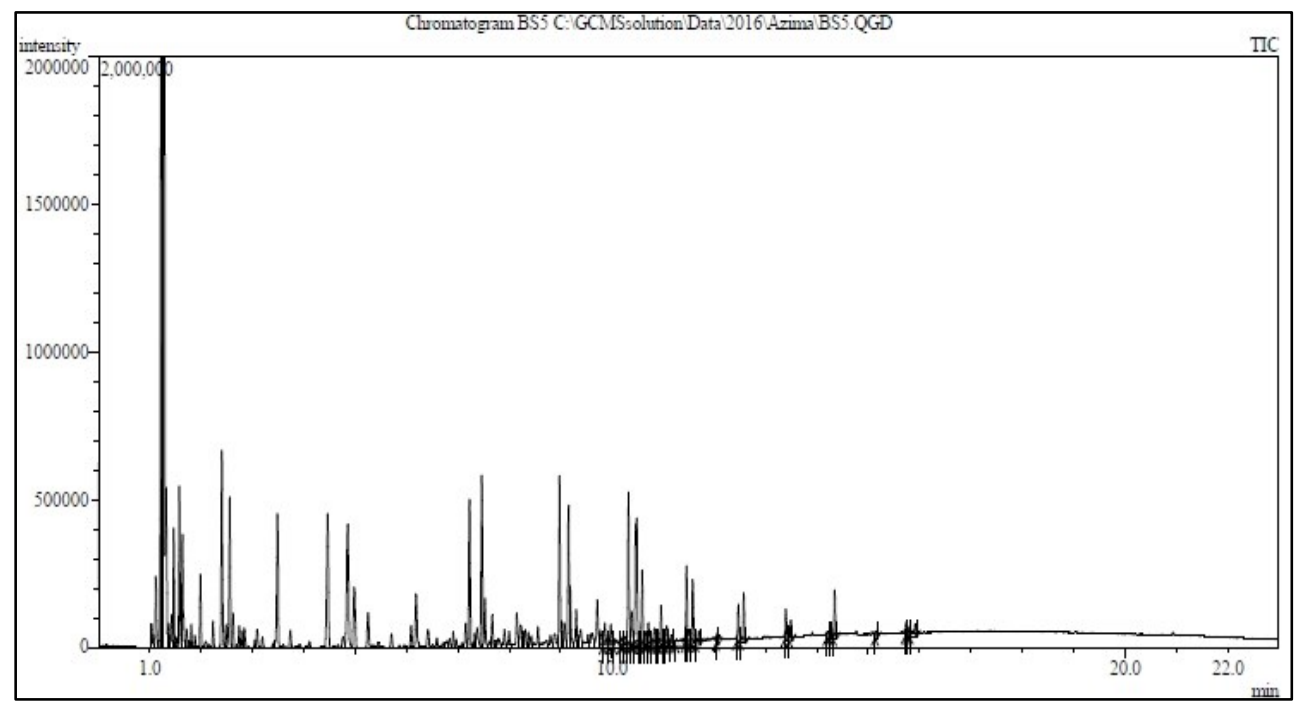

Figure 6. TIC of burned porcine bone (Set 6)

While majority of the compounds appeared in at least four of the total six repetitions, alcohol (nonanol), $n$-alkene (1-pentadecene) and nitrile (hexadecanitrile) only appeared in three or less repetitions. Meanwhile, hexadecanitrile was only present in three out of the six repetitions, although a small peak in every chromatogram with $\mathrm{m} / \mathrm{z}$ values of 38 and 44 were consistently detected across six repetitions. It's absence could potentially be due to the decomposition and fragmentation of hexadecanitrile into smaller daughter fragments that rendered it undetectable in the GC-MS. Similar to the indoor burning data in Gabriel's research [7], this work (Table 1) also documented the presence of dimethyl-disulfide and dienes, although inconsistently across the repetitions. The present of furan in this work could be due to the variation in the environmental conditions exposed particularly the auto-ignition of fat that occurred multiple times in one complete cycle of burning as shown in Figure 7(a).

Higher temperature with broader exposure durations have been documented in the literature to cause the volatilization of low vapour pressure (higher molecular weight) $n$-alkanes and $n$-alkenes [14]. Although this experiment attained sufficient temperatures to volatilise these compounds, the inconsistencies in the presence of high molecular weight $n$-alkanes and $n$-alkenes in this work (Table 1) could be due to the short length of exposure and multiple ignitions experienced, as illustrated in Figure 7(a).

The differences in the time-temperature profiles of six replicates of porcine bone samples across indoor laboratory and outdoor burning conditions are illustrated in Figure 7. The initial temperature of all laboratory samples in Figure 7(b) increased rapidly and attained temperatures above $250{ }^{\circ} \mathrm{C}$ after seven minutes. This was not the case for outdoor samples in Figure 7(a) as most samples attained temperatures of $250{ }^{\circ} \mathrm{C}$ within one minute. In Figure $7(\mathrm{a})$, it is clearly seen that the ignition of fat occurred several times for sets 1,2 and 4, but died down almost instantly before the final ignition that lasted for five minutes. It is noted that the ignition of fat in set 2 occurred once at 300 seconds but instantly died off and ignited again at 500 seconds. This was not the case for laboratory burning as the ignition of fats occurred once and could sustain itself for five minutes as shown in Figure 7(b). This occurrence could be due to the variation in the concentration of oxygen that is largely controlled by wind conditions in outdoor burning [15]. On the contrary, in indoor burning, the supply of oxygen was steady and controlled throughout the entire experiment, facilitating a steady and long-lasting flame [16]. It is also noted in Figure 7(b) that the maximum temperature attained in indoor burning was above $700{ }^{\circ} \mathrm{C}$. As for the outdoor burning, the maximum temperature attained as illustrated in Figure 7(a) was only $580{ }^{\circ} \mathrm{C}$. The differences in temperatures attained could also be due to the variations in oxygen availability that could alter the burning efficiency $[15,16]$. 

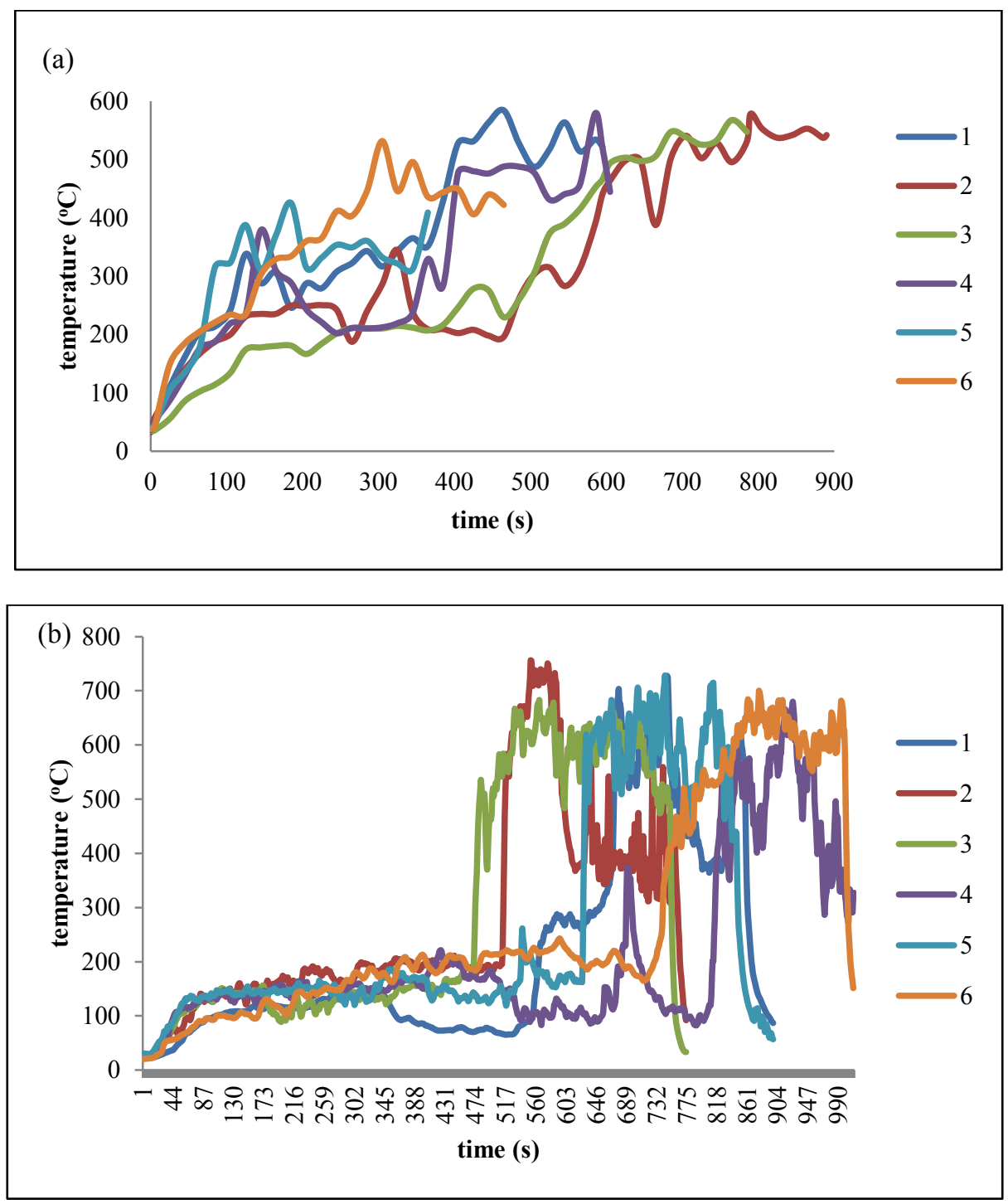

Figure 7. Overlay of six time-temperature profiles of (a) outdoor burning condition and (b) indoor laboratory burning condition [7]

Pyrolysis products generated from the outdoor burning of porcine bone samples that consistently appeared across six repeats were found to be similar with those generated from indoor laboratory burning condition as displayed in Table 2. These include $\mathrm{C}_{8}$ to $\mathrm{C}_{16} n$-alkanes and $n$-alkenes (1-octene, octane, 1-nonene, nonane, 1 -decene, decane, 1 undecene, undecane, 1-dodecene, dodecane, 1-tridecene, tridecane, 1-tetradecene, tetradecane, pentadecane, 1hexadecene) and aromatic compounds (benzene, toluene, ethyl-benzene, propyl-benzene). Five volatile compounds that were detected consistently in this work but not consistent in indoor laboratory burning are methyl-cyclopentane, 3-methyl-butananitrile, 2-octene, butyl-benzene and pentyl-benzene. The presence of $n$-aldehydes (pentanal and hexanal) in this work was the major differences noted in terms of pyrolytic profiles when compared to indoor laboratory burning condition. No $n$-aldehydes were detected from indoor laboratory burning of porcine bone samples that were exposed to temperatures above auto-ignition $\left(250^{\circ} \mathrm{C}\right)$ [7] under longer burning durations above 900 seconds. 
Similar findings were also noted by Purevsuran et al. [17] for their samples that were exposed to temperatures above 500 to $700{ }^{\circ} \mathrm{C}$ under extended burning durations of about 4 to 5 hours. However, $n$-aldehydes were detected in the pre-ignition samples (temperatures below $300^{\circ} \mathrm{C}$ ) in Gabriel's work [7] under indoor laboratory burning conditions. Contrary to Gabriel [7] and Purevsuran et al.'s [17] finding, DeHaan et al. [8] detected the present of straight chain $n$-aldehydes at high temperature (above $700{ }^{\circ} \mathrm{C}$ ) but with shorter burning durations of ten seconds. The presence or absence of $n$-aldehydes as a by-product of pyrolysis from porcine bone samples is largely related to the temperature in which the samples were exposed; higher temperature induces the decomposition and oxidation of $n$-aldehydes into smaller compounds and renders it undetectable by the instrument $[8,9]$. The presence of $n$-aldehyde in this work may be due to the lower temperature profiles experienced by the sample and the multiple ignitions as illustrated in Figure 7(a). Besides temperature, the exposure duration also plays an important role in the detection of $n$-aldehydes [7]. In the indoor laboratory burning conditions [7] and in Purevsuren et al.'s [17] work, burning occurred for extended periods of more than 900 seconds and 4 hours respectively as compared to DeHaan et al.'s work [8] (ten seconds) and the outdoor burning conditions in this work (800 seconds), where burnings were shorter, thus preserving the $n$-aldehydes from being decomposed or totally consumed during the burning process [7].

Table 2. Comparison of pyrolysis products that were detected consistently across six sets of repeats between indoor and outdoor burning conditions [7]

\begin{tabular}{|c|c|c|}
\hline No. & $\begin{array}{l}\text { Compound } \\
\text { (Outdoor Burning) }\end{array}$ & $\begin{array}{l}\text { Compound } \\
\text { (Indoor Laboratory Burning) }\end{array}$ \\
\hline 1. & 1-butene & benzene \\
\hline 2. & methyl-cyclopentane & toluene \\
\hline 3. & benzene & 1-octene \\
\hline 4. & pentanal & octane \\
\hline 5. & 3-methyl-butanitrile & ethyl-benzene \\
\hline 6. & toluene & $p$-xylene \\
\hline 7. & 1-octene & 1-nonene \\
\hline 8. & octane & nonane \\
\hline 9. & 2-octene & propyl-benzene \\
\hline 10. & ethyl-benzene & 1-decene \\
\hline 11. & 1-nonene & decane \\
\hline 12. & nonane & 1-undecene \\
\hline 13. & propyl-benzene & undecane \\
\hline 14. & 1-decene & 1-dodecene \\
\hline 15. & decane & dodecane \\
\hline 16. & butyl-benzene & 1-tridecene \\
\hline 17. & 1-undecene & tridecane \\
\hline 18. & undecane & 1-tetradecene \\
\hline 19. & pentyl-benzene & tetradecane \\
\hline 20. & 1-dodecene & 1-pentadecene \\
\hline 21. & dodecane & pentadecane \\
\hline 22. & 1-tridecene & 1-hexadecene \\
\hline 23. & tridecane & hexadecane \\
\hline 24. & 1-tetradecene & 1-heptadecene \\
\hline 25. & tetradecane & heptadecane \\
\hline 26. & pentadecane & hexadecanitrile \\
\hline 27. & 1-hexadecene & \\
\hline
\end{tabular}

*bold text refer to the compound that appeared for both condition 


\section{Conclusion}

Indoor laboratory burning conditions generated consistent results in terms of the pyrolysis products generated and the time-temperature profiles in comparison to outdoor burning conditions. Pyrolytic data generated in this work were determined to be in the range of $n$-alkanes, $n$-alkenes, $n$-aldehydes, aromatics and nitrile compounds, similar to those obtained from indoor laboratory burning but with the additional presence of $n$-aldehydes. Results from this study has indicated the human pyrolytic data model generated indoors to be a good representative of outdoor conditions and has also successfully clarified the inconsistencies in terms of the presence and absence of $n$ aldehydes from porcine and human pyrolytic data. The use of activated carbon tablet as a substitute of activated carbon strip (ACS) for the adsorption of pyrolytic products is also highlighted in this work.

In terms of future prospects, pyrolytic experiments using other parts of the porcine carcass would be an advantage. This will reveal further information about the type and consistency of pyrolysis products generated by different types of tissues in a fire. In addition, it would also be particularly interesting to explore the origin of porcine tissues that have been subjected to burning in the presence of ignitable liquids and clothing material. Data generated from this process would be helpful in identifying the effects of interfering products that can possibly be generated, if any, on the key indicators of human remains in the presence of contaminants.

\section{Acknowledgement}

The authors would like to appreciate Faculty of Health Sciences, Universiti Kebangsaan Malaysia for the facilities and support that are provided for this study. We would also like to extend our gratitude to The Centre for Water Research and Analysis (ALIR), UKM for collaboration in providing the facilities which is a freezer to store the bone samples.

\section{References}

1. Fanton, L., Jdeed, K., Tilhet-Coartet, S. and Malicier, D. (2006). Criminal Burning. Forensic Science Institute, 158 (2-3): $87-93$.

2. Porta, D., Poppa, P., Regazzola, V., Gibelli, D., Schillaci, D. R., Amadasi, A., Magli, F. and Cattaneo, C. (2013). The importance of an anthropological scene of crime investigation in the case of burnt remains in vehicles: 3 case studies. American Journal of Forensic Medicine and Pathology, 34(3): 195 - 200.

3. Ubelaker, D. H. (2009). The forensic evaluation of burned skeletal remains: A synthesis. Forensic Science Institute, 183 (1-3): $1-5$.

4. Knight, B. and Saukko, P. J. (2004). Knight's Forensic Pathology. Third ed. Edward Arnold Publisher Ltd, London.

5. Holden, J. L., Phakey, P. P. and Clement, J. G. (1995). Scanning electron microscope observations of heattreated human bone. Forensic Science Institute, 74 (1-2): 29 - 45.

6. National Centre For Forensic Science (NCFS). (2006). Substrate database. University of Central Florida.

7. Gabriel, G. F. (2015). The analysis and discrimination of pyrolysis products from biological and non-biological sources. Central of Forensic Science, Department of Pure and Applied Chemistry. University of Strathclyde.

8. DeHaan, J. D., Brien, D. J. and Large, R. (2004). Volatile organic compounds from the combustion of human and animal tissue. Science and Justice, 44 (4): 223 - 236.

9. Agu, K. (2011). Investigation of the thermal degradation products of bone. Centre for Forensic Science, Department of Pure Science and Apllied Chemistry. University of Strathclyde.

10. American Society for Testing and Materials (ASTM) International E1412-07 (2012). Standard practice for separation of ignitable liquid residues from fire debris samples by passive headspace concentration with activated charcoal. American Society for Testing and Materials (ASTM) International. West Conshohocken, PA.

11. Pearce, A. I., Richards, R. G., Milz, S., Schneider, E. and Pearce, S. G. (2007). Animal models for implant biomaterial research in bone: A review. Europe Cells and Materials Journal, 13:1 - 10.

12. Mosekilde, L., Kragstrup, J. and Richards, A. (1987). Compressive strength, ash weight, and volume of vertebral trabecular bone in experimental fluorosis in pigs. Calcified Tissue International, 40(6): $318-322$.

13. Thorwarth, M., Schultze-Mosgau, S., Kessler, P., Wiltfang, J. and Schlegel, K. A. (2005). Bone regeneration in osseous defects using a resorbable nanoparticular hydroxyapatite. Journal of Oral and Maxillofacial Surgery, 63(11): $1626-1633$. 
14. Stauffer, E. (2003) Concept of pyrolysis for fire debris analysis. Science and Justice. 43 (1): 29-40.

15. National Fire Protection Association (NFPA). (1990). Fire Protection Handbook. National Fire Protection Association (NFPA), Standard Publishing Company.

16. Welker, J. R. and Sliepcevich, C. (1966). Burning rates and heat transfer from wind-blown flames. Fire Technology, 2(3): $211-218$.

17. Purevsuren, B., Avid, B., Garelmaa, T., Davaajay, Y., Morgan, T., Herod, A. and Kandiyoti, R. (2004). The characterisation of tar from the pyrolysis of animal bones. Fuel, 83 (7-8): $799-805$. 